\title{
Norois
}

Environnement, aménagement, société

$254 \mid 2020$

Vins, vignobles et viticultures atlantiques

\section{Pierre MASSOTTE, Le défi des vins doux naturels}

\section{Pierre Giresse}

\section{OpenEdition \\ Journals}

Édition électronique

URL : https://journals.openedition.org/norois/9687

DOI : $10.4000 /$ norois. 9687

ISSN : $1760-8546$

\section{Éditeur}

Presses universitaires de Rennes

\section{Édition imprimée}

Date de publication : 30 juin 2020

Pagination : 109-110

ISBN : 978-2-7535-8119-7

ISSN : 0029-182X

\section{Référence électronique}

Pierre Giresse, "Pierre massotte, Le défi des vins doux naturels », Norois [En ligne], 254 | 2020, mis en ligne le 30 juin 2020, consulté le 03 janvier 2023. URL : http://journals.openedition.org/norois/9687 ; DOI : https://doi.org/10.4000/norois.9687 


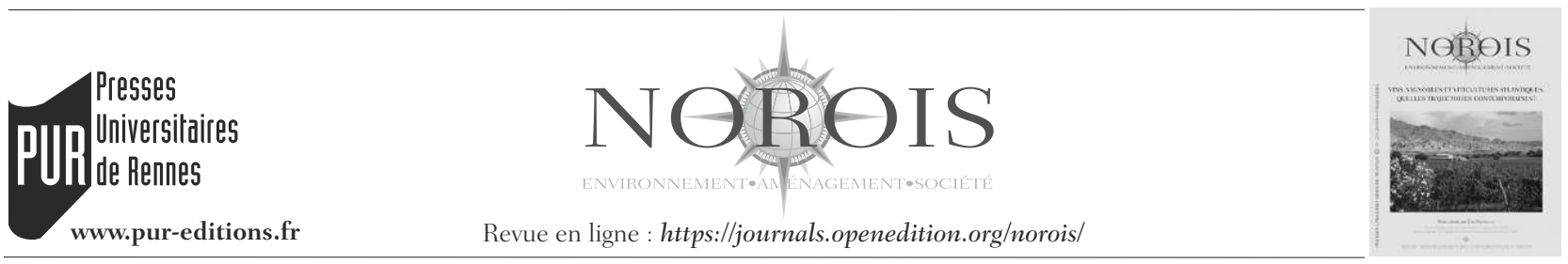

\section{COMPTE RENDU BIBLIOGRAPHiQUe}

Pierre Massotte, Le défi des vins doux naturels, Londres, Iste éditions, collection « Agriculture et Agronomie », 2017, 567 p.

Il s'agit d'un volumineux livre de près de 570 pages que l'auteur, plusieurs fois, qualifie plaisamment de «petit ouvrage ». Les éclairages apportés, de nature très polydisciplinaire, confèrent un aspect un peu encyclopédique à un volume qu'on pourrait supposer écrit à plusieurs mains, mais il n'en est rien : c'est bien toujours du même auteur qu'il s'agit. On peut juger de la performance à la lecture des dix-neuf chapitres d'une longue rédaction dont je ne fais que résumer les propos : économie agricole, art de la dégustation, physiologie et fondements biochimiques du goût, réglementation et législation, environnement physique de la vigne, techniques de vinification, génétique des cépages, méthodes de vendange, processus de mutages (et de vieillissement), intelligence artificielle, agriculture biologique et biodynamique, nanotechnologies et robotique, biochimie des levures et des enzymes, sérempidité (je ne savais pas ce que c'était...) et, enfin, gastronomie catalane. Le même auteur intervient tour à tour comme économiste, dégustateur, physiologiste, voire neuro-biologiste, chimiste, commerçant, environnementaliste, œnologue, généticien, modélisateur, viticulteur (tout simplement), économiste encore et finalement gastronome. En vérité, il y a plusieurs livres en un seul. L'entreprise est audacieuse, on admettra donc que dans ces travaux d'Hercule, quelques passages puissent pêcher par approximation (comme pour le contexte géologique, par exemple).

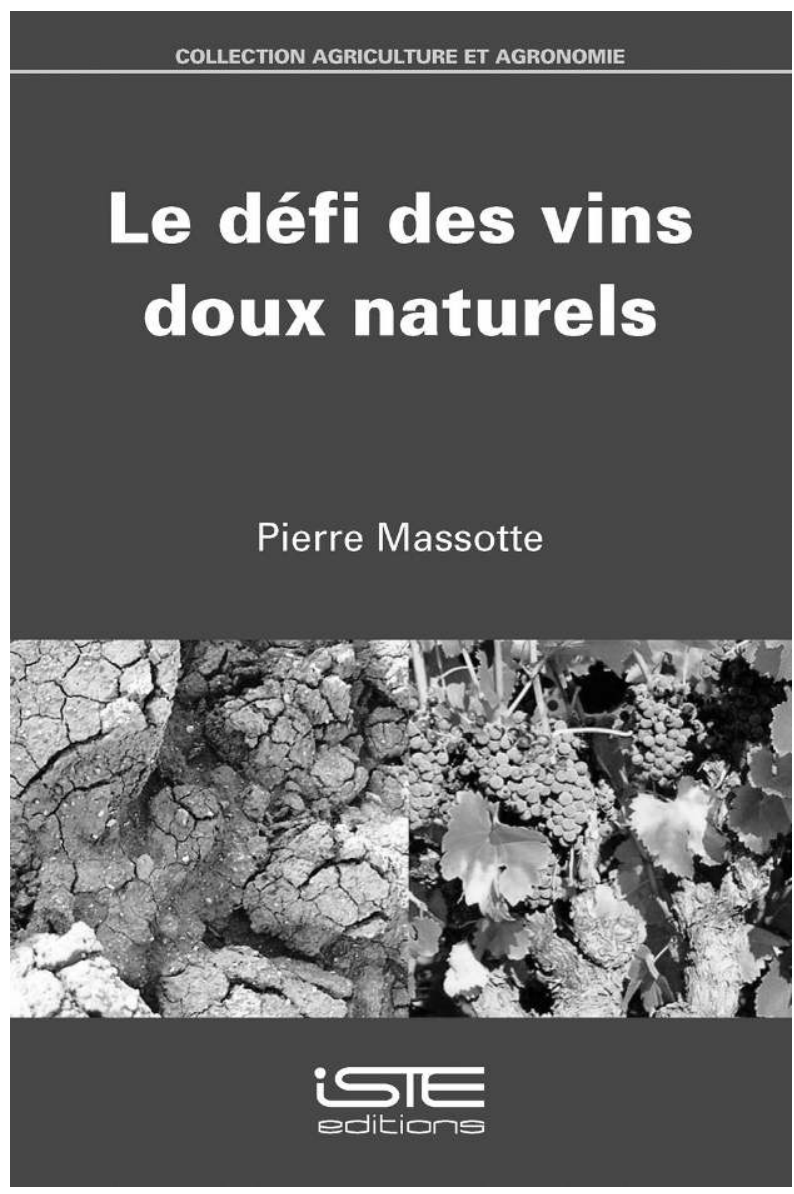

Le style est vif et agréable, le ton convaincu et parfois passionné; je penserais que cet homme dans son quotidien doit être très bavard car son livre est volu- 
bile. L'érudition est étourdissante, mais les digressions trop fréquentes. Cela ne va pas sans quelque inconvénient : j'ai eu du mal à suivre l'articulation de l'exposé en général, mais aussi à l'échelle réduite de certains chapitres dont l'homogénéité et la logique ne sont pas toujours respectées, un peu comme si ce livre avait été écrit en plusieurs fois, qu'on s'oubliait et qu'on en venait parfois à se répéter un peu. Combien de fois est-il question du bon docteur Arnau de Villeneuve? À cet égard, l'insertion in fine d'importantes annexes n'était sans doute pas indispensable, elles viennent encore ajouter à la redondance.

Ce livre que, par certains aspects, on pourrait qualifier de Traité, s'affranchit des règles de la rédaction scientifique; il ne sépare pas nettement le connu du nouveau. On y trouve tour à tour des exposés pédagogiques (où les références sont parfois oubliées), des chroniques, des témoignages ou encore des pamphlets plus ou moins polémiques. Les juxtapositions sont parfois étonnantes. Il est question des axes de recherche qui concernent la complexité et la «simplexité »-ici, ce serait plutôt le premier terme qui a été privilégié. J'ai noté que l'auteur a été professeur de génie industriel, une compétence qui transparaît dans plusieurs chapitres de managérat économique, mais il fait partie d'une famille de tradition viticole et plus encore de tradition catalane, deux appartenances qui colorent fortement nombre de pages.
«Le défi des vins doux naturels », tel est le titre... à la fin de la lecture, on peut se demander s'il est justifié. De nombreux et longs chapitres sont écrits sans réminiscence aucune à ce titre; plus loin, ces vins doux sont ponctuellement présentés, sans qu'on puisse trouver d'explication à ce "défi ", ni à la manière de le relever. Tout un chapitre est dédié à la notion de bonheur - le lecteur trouvera assurément plusieurs épisodes de bonheur dans cette lecture... mais cependant pourquoi ce titre? Alors que le propos déborde souvent de l'hexagone, ces vins doux ne sont regardés qu'à l'échelle du seul Roussillon, ou peu s'en faut. L'avant-propos laisse à penser que la production des vins doux naturels est menacée, que des questions de survie se posent, mais que la potentialité est plus forte que pour les vins secs, il faudra s'en contenter.

Les champs de la rédaction sont tellement larges que tout lecteur est censé y apprendre quelque chose. À un endroit, je crois, l'auteur laisse entendre qu'il veut s'adresser aux producteurs et aux consommateurs des vins doux naturels, vaste public sans doute.

J'oubliais : la sérempidité, c'est le don de faire des trouvailles. Le terme s'applique au lecteur de cet ouvrage.

Pierre GiResse Université de Perpignan 